\title{
Analysis on Internationalization of RMB and Economic Openness
}

\author{
Yao Yao
}

Hangzhou Institute of Service Engineering, Hangzhou Normal University, Hangzhou, 311121, China

yyaoexist@163.com

Keywords: Internationalization of RMB; Economic openness, Risk management; Regulation

\begin{abstract}
The internationalization of RMB became an important issue in China's economy, especially after international financial crisis, which has positive effect in promoting economic openness. This paper analyzed risk factors include short term international capital flow, financial fragility, regulation and policy, and provides some coping strategies. This paper also analyzed mutual relation between currency internationalization and economic openness by examine the interaction between internationalization of RMB a foreign trade, regional economic cooperation, and influence in world economy.
\end{abstract}

\section{Introduction}

After international financial crisis in 2008, the internationalization of RMB became an important issue in China's economy. With current account convertibility and gradual opening up of capital account, the currency internationalization has been developing rapidly. With its admission into SDR currency basket in 2015, RMB is playing more and more role in global economy. More offshore RMB center has been established, more currency swap agreement has been signed, and overseas bond issuance has been accelerated. This paper will analyze the risk management of RMB internationalization, as well as its influence on economic openness and overall macro economy. The paper is structured as follows: the first section gives introduction of the topic, the second section illustrates and analyzes the development of internationalization of RMB, the third section analyzes the issue of potential risks and risk management, thefourth part examines the relation between internationalization of RMB and macro economy, the last part concludes.

\section{Development of Internationalization of RMB}

After several progressive exchange rate system reforms, and gradual open up of current account and part of capital account, the launch of cross border settlement, the internationalization of RMB is right on path. The internationalization of RMB, driven by the development of international trade and outward direct investment, the large scale of foreign exchange reserve, would have the benefit of participate in the international monetary system, diversify asset internationally, less foreign exchange risk exposure in international economic activities and international currency seignior revenues. The internationalization of RMB interacts with the development of offshore market. The belt and road strategy also requires the support from currency internationalization.

RMB is admitted into the currency basket of SDR by IMF In 2015, which indicated that RMB is considered international currency. With a weighting of over $10 \%$, which is weighing more than Japanese Yen and pound sterling, the currency is accepted by the international financial market. The international community acknowledged the position of the currency, as well as the role China play in international market. The role of RMB would be more important in international financial market. As part of international monetary system, admitting in SDR basket indicate the relatively high level of RMB internationalization, and its future development.

The information infrastructure is improved for the internationalization of RMB. The cross border settlement, which was launched in 2009, requires information infrastructure. RMB cross-border payment system, named CIPS, successfully launched on the line. CIPS provides cross border settlement services for financial institutions in and out of the country, as well as offshore institutions. 
The system covers time zone all over the world to facilitate international settlement in RMB, provide services to o ver 100 banks and other institions globally.

The quotation mechanism between US dollar and RMB is more flexible and marketized.The perfection of the exchange rate index system with the development of international trade and outward direct investment, as well as the development in domestic financial market. The middle price of exchange rate forming mechanism was reformed to increase marketization degree of foreign exchange market. Market makers would combine international market exchange rate with the demand and supply of foreign exchange, to give reasonable quotations. RMB exchange rate index is also compiled and published by China foreign exchange trade center, with a weighted basket of currencies. The currency basket and weight are determined by international economic activities. The transparency of policy is enhanced. The exchange rate would reflect its market value more accurately. The pricing mechanism of RMB is more independent, with less intervetion.

The reforms in domestic financial market has positive effects in RMB internationalization. The progressive reform of liberalization of interest rate, gradully achieved its goal, with no upper limit nor lower limit, on either lending or borrowing rate. With the marketlization of interest rate, leverage function of interest rate gives more power to monetary policy, enhances efficiency in fund allocation. Deposit insurance system and legislations provide safety net to banking sector in case of internationalization of financial market. Bond market improved, treasury bond yield curve is compiled, short term bonds would be issued recurrently. Pirce discovering function of domestic bond market provides liquidity for the market of RMB.

The bond market is more internationalized. The degree of openness in bond market is increased. Foreign financial institutions, include central banks, international financial institutions and sorveign wealth funds, no longer need approval to the interbank bond market. The overseas investors could invest in spot transaction, repo, forward transction in bond market and bong lending. The panda bond market developed rapidly. The scale of panda bond increased fast. It also attracted more investors, include sorveign investors. The firm are permitted to raise funds overseas. The transfer from approval system to record system, issuing bond overseas by corporate is part of open up capital account. The belt and road strateguy and other policy requires the fundings internationally. Offshore market bonds in RMB and other investment instruments developed under the new record system.

Central bank notes of China launched into international market in 2005, provide more financial instrument in offshore RMB market. Central bank note boosts confidence in RMB, promote international demand for RMB, facilitate foreign trade and investment. The rate of central bank notes provides benchmark price of RMB in overseas market. Established by Shanghai stock exchange, Deutsche exchange group and China Financial Futures Exchange, China Europe international exchange was established to provide investors from Europe and all over the world with financial products and services denominated in RMB. In the future, the international exchange could evolve into a comprehansive exchange, provides equity and bond trade services.

\section{Potential Risks in RMB Internalization and Management}

Although internationalization of RMB has positive effect in promoting economic openness, there are some challenges in international of RMB, concerning financial stability and regulation efficiency.

Short Term International Capital Flow. Short term international capital flow tends to be unstable. Short term capital flow is driven by investors portfolio management decision which weighing between financial asset return and risks. It also indicates investment advantage of institutional investor in international financial market. The large scale of short term international capital flow, which could lead to short term capital accumulation and reversal, has negative financial and economical effect. In extreme circumstances, destructive international capital shock could happen. With the background of hot money inflow, the internationalization of RMB could bring more unregulated hot money into domestic financial market. 
Financial Fragility. Financial system in developing countries is not maturely established, the regulation of financial sector may also underdeveloped and less efficient. Developing countries, especially emerging economies are more likely to be target of speculation capital. Open economic policy and insufficient regulation and immature domestic financial market, makes emerging market easy targets for international speculators. Currency internationalization enhances systematic risks of financial market. Uncertainties in international market could transmit to domestic market more rapidly. Volatility of exchange rate as inevitable consequence of currency internationalization would also be risk factor in international trade and investment.

Regulation and Policy. The independence of monetary policy, according to Meade Conflict, would be undermined under free international capital flow. The efficiency of fiscal policy and monetary policy could be compromised. The regulation would be much more complicated. International capital flow makes regulation difficult and less efficient. Adjustment of balance of payment may not achieve expected targets, internationalization of RMB could lead to current account deficit, inflation and debt repayment risk. Internationalization of home currency make international financial risks and financial crisis become much more contagious, and transfers much more rapidly. Currency internationalization increases difficulty for central bank to make monetary policy, for influence from international market should be taken into consideration in policy making.

Risk Management Measures. A well established, modern financial system which has the ability to adjust and tackle risk factors in international capital flow would be necessary. Cultivate a mature financial market, establish and perfect domestic financial system, develop real economy which is foundation for a healthy financial system, would be prerequisite in RMB internationalization. The flexibility and adaptability of financial market would be crucial in risk management.Foreign exchange management would be more important, for short term capital flows and exchange rate volatility following internationalization of RMB. The regulation and management of hot money and speculations, and exchange risk management system, are crucial components in regulation in the future.Flexible monetary policy, open capital account progressively, would also be important in risk management. Improve the level of policy making of the central bank, promote the transparency in policy making process, select proper intermediate target and ultimate objective, lead expectation of the public efficiently.Financial market warning mechanism, especially in banking sector, need to be established. To prevent international contagion of financial risk, even financial crisis, a sound and comprehensive warning system would be required in the process of currency internationalization. Financial innovation and necessary hedging instrument can be applied in risk management.The legal system in the financial sector is still relatively weak and imperfect. Internationalization of RMB is calling for a sound legal system to regulate financial sector. It is urgent to establish and perfect financial legislation.

\section{Internationalization of RMB and Economic Openness}

The overall openness of China's economy is the foundation of internationalization of RMB. The dominant position of RMB in international trade settlement in neighboring nations, and its role as the common settlement currency in ASEAN countries, provide international trade basis for the internationalization of RMB. The rapid growth and stability of macro economy in China attracts investors from all over the world, provides international investment basis for the internationalization of RMB. The internationalization of RMB would improve China's influence in world economy, improve the international status of China.

Internationalization of RMB and Foreign Trade. The internationalization of RMB would promote international trade. Enhancing RMB's position as settlement currency in neighboring nations, increasing its liquidity, facilitating settlement, increasing the scale of RMB in trade and investment, such measures would promote currency internationalization, while facilitate and promote international trade as well. 
Internationalization of RMB and Internationalization of China's Financial System. Offshore $\mathrm{RMB}$ market is an experiment phase of internationalization of RMB, offshore RMB market would involve the location of financial market, issuing country, the affiliation of financial institution, financing country and investing country. The offshore financial market would help China's financial system to be more adapt to international financial activities.

Internationalization of RMB and Regional Economic Cooperation. Internationalization of RMB would promote regional coordinated development. RMB plays an important role in regional economic cooperation, especially in neighboring district. The currency integration among Mainland, Hong Kong and Taiwan, with a similar approach as the Euro, would promote regional integration and coordinated development. Improve the internationalization of RMB by other free exchanged currencies. Based on the platform of ASEAN, establish the dominant position of RMB in Asian monetary system. Promote trade and financial activities in Asia, enhancing the role of settlement currency, promoting RMB internationalization while promoting Asian economic cooperation.

Internationalization of RMB and China's Influence in World Economy. When RMB become an international currency, China's discourse in global economy would increase. China would have more global influence, the influence of China internationally would positively interact with economic growth at home. In economic system, economic growth and finance would develop coordinately and promote mutually. Internationalization of RMB, especially capital account convertibility, would increase efficiency of financial market, open up overseas financial resource, so as to promote economic growth. While economic growth through international trade and investment, would in turn help opening up capital account.

\section{Conclusion}

The internationalization of RMB became an important issue in China's economy, especially after international financial crisis. Although internationalization of RMB has positive effect in promoting economic openness, there are some challenges in international of RMB. This paper analyzes short term international capital flow, financial fragility, regulation and policy, and provides some coping strategies, such as establishing sound financial system and legal system, efficient foreign exchange management, flexible monetary policy, financial market warning mechanism. The internationalization of RMB and economic openness has mutual influence, and is mutually promoted. It interacts with foreign trade, regional economic cooperation, and influence in world economy.

\section{Acknowledgement}

This study is supported by the Natural Science Foundation of Zhejiang Province, Research on financial time series data mining, LQ15F020013.

\section{References}

[1] H. Dong, X. Yu. Network effects in currency internationalization: Insights from BIS triennial surveys and implications for the renminbi, Journal of International Money \& Finance. 68 (2016) 203-229.

[2] Q. He, I. Korhonen, J. Guo, F. Liu, The geographic distribution of international currencies and RMB internationalization, International Review of Economics \& Finance. 42 (2016) 442-458.

[3] J. Wang, Overnight price discovery and the internationalization of a currency: The case of the Korean won, Pacific-Basin Finance Journal, 29 (2014) 86-95.

[4] D. Tobin, Renminbi internationalisation: precedents and implications, Journal of Chinese Economic \& Business Studies, 11 (2013) 81-99. 
[5] Z. Zhang, A.J. Makin, Q. Bai, Yen internationalization and Japan's international reserves, Economic Modeling, 52 (2016) 452-466.

[6] X. He. Issues Surrounding Internationalization of China's Currency, Journal of Management Policy \& Practice, 15 (2014) 20-29.

[7] M. Kawai, V. Pontines, Is there really a renminbi bloc in Asia?: A modified Frankel-Wei approach, Journal of International Money and Finance, 62 (2016) 72-97.

[8] C. Shu, D. He, X. Cheng, One currency, two markets: the renminbi's growing influence in Asia-Pacific, China Economic Review, 33 (2015) 163-178.

[9] A. Bénassy-Quéré, D. Capelle, On the inclusion of the Chinese renminbi in the SDR basket, International Economics, 139 (2014) 133-151.

[10] Information on http://www.safe.gov.cn 